\title{
AMPLIFICATION OF G-ERBB2 PROTO-ONCOGENE AND IMMUNOHISTOCHEMICAL EXPRESSION OF C-ERBB2 GENE PRODUCT IN PARATHYROID TUMORS
}

\author{
Nobuo MORIYAMA ${ }^{1}$, Eiji HIGASHIHARA ${ }^{2}$, Tetsuo UEKI ${ }^{1}$, Yoshio HOSAKA ${ }^{2}$, \\ SHIGEHARU KURIMOTO ${ }^{1}$, YASUNORI ISHII ${ }^{3}$, \\ Atsushi TAJIMA ${ }^{1}$ and Yoshio ASO $^{2}$
}

\begin{abstract}
Department of Urology ${ }^{1}$, Branch Hospital, Faculty of Medicine, The University of Tokyo, Tokyo 112, Department of Urology ${ }^{2}$, Faculty of Medicine, The University of Tokyo, Tokyo, 113 and Department of Urology ${ }^{3}$, Saitama Central Hospital, Saitama, 336
\end{abstract}

Received for publication December 20, 1991 and in revised form January 27, 1992

\begin{abstract}
To examine whether or not a part of human parathyroid adenomas have a malignant potential, 15 parathyroid tumors including 13 adenomas, 1 hyperplasia and 1 adenocarcinoma were studied for the amplification of the c-erbB2 proto-oncogene. Eleven adenomas of these tumors were also evaluated for the immunohistochemical expression of the c-erbB2 gene product. The amplification of the c-erbB2 proto-oncogene (2-fold or more greater than control) was recognized in 3 adenomas $(23.1 \%$ of all adenomas) and 1 adenocarcinoma as compared to a pooled human normal placenta, which serves as control. Six out of 11 parathyroid adenomas $(54.5 \%)$ revealed the immunohistochemical expression of the c-erbB2 gene product on the cell membrane and in the cytoplasm. Three adenomas $(27.2 \%)$ showed the strongly positive (H) staining and the other 3 adenoma $(27.2 \%)$ showed the weakly positive $(+)$ staining. The 2 cases having the amplification of the c-erbB2 proto-oncogene also revealed the strongly positive staining. The c-erbB2 proto-oncogene, which has been reported to be amplified or expressed in some adenocarcinomas, might be associated with the initiation and progression of some parathyroid adenomas. The present findings might suggest that some parathyroid adenomas could have a malignant potential.
\end{abstract}

The differential diagnosis among the parathyroid hyperplasia, adenoma and adenocarcinoma is sometimes difficult by the histological examination. Metastasis is the key point in separating malignant tumors from benign tumors (4). Some parathyroid adenomas and adenocarcinomas might have the same etiologic factors such as the neck irradiation $(5,11)$, or some adenomas might have the malignant potential.

It has recently become increasingly clear that oncogenes may initiate and promote the development of various human malignant tumors $(3,16)$. Furthermore, Kremer et al. (12) also reported rapid transient rise in c-myc and c-fos oncogene mRNA before parathyroid cell proliferation. Allelic loss from

Corresponding address: Nobuo MORIYAMA, M.D., Department of Urology, Branch Hospital, Faculty of Medicine, The University of Tokyo, 3-28-6 Mejirodai, Bunkyo-ku, Tokyo 112, Japan. chromosome 11 was found in the parathyroid tumors in patients with multiple endocrine neoplasia type 1 (21) and in the sporadic parathyroid adenomas (8, 21). In this chromosome, the six loci, beta-globin, parathyroid hormone, oncogene c-Ha-ras-1, insulin, calcitonin and catalase loci, have been mapped (15). Another genetic abnormality, such as DNA rearrangement in PTH gene was also recognized in parathyroid tumors $(1,9)$.

It may also be necessary for the other oncogenes to be evaluated for the development of parathyroid adenomas and adenocarcinomas. In the present study, to clarify whether some parathyroid adenomas have malignant potential, the amplification of the cerbB2 proto-oncogene and the immunohistochemical expression of its product were evaluated in the parathyroid adenoma and adenocarcinoma, because this oncogene has been reported to be amplified or expressed in some adenocarcinomas $(2,16,18,22)$ and 
the transitional cell carcinoma of the bladder (17), but not in the parathyroid adenoma and adenocarcinoma.

\section{MATERIALS AND METHODS}

Fifteen patients with parathyroid tumors were evaluated. The tumors consisted of 13 adenomas, 1 hyperplasias, and 1 adenocarcinoma with cervical lymph node metastases. The weight of the adenoma and hyperplasia ranged from $0.2 \mathrm{gm}$. to $9.4 \mathrm{gm}$., while the adenocarcinoma weighed $30 \mathrm{gm}$. One patient showed the coincident papillary thyroid carcinoma. The patients were followed-up for 12 to 40 months after surgery. Those with adenomas showed no evidence of metastasis or recurrence, but the patient with adenocarcinoma developed cervical lymph node metastases which were verified microscopically 9 months later. All patients have no history of neck irradiation. A summary of the features of the patients is shown in Table 1. As soon as the surgical tumor specimens were available, a part of the samples was stored at $-70^{\circ} \mathrm{C}$ until extraction of DNA. the other part of samples was immediately mounted into OCT compound, followed by rapid freezing within liquid nitrogen, and stored at $-70^{\circ} \mathrm{C}$ until the immunohistochemical procedures.

\section{Amplification}

The 3.4 kilobase (kb) cDNA sequence (pEB45) of the human c-erbB2 was used for DNA-probe.

The genomic DNA was extracted from the tumor tissues and pooled human placenta as control by established methods (14). All of the samples were treated with $100 \mu \mathrm{g} / \mathrm{ml}$ of DNase-free RNase at $37^{\circ} \mathrm{C}$ for $3 \mathrm{hr}$ before the extraction of DNA with phenol/chloroform. Five $\mu \mathrm{g}$ of DNA was digested with EcoRI restriction endonuclease (Takara Shuzo, Co., LTD., Kyoto, JAPAN). The slot blot hybridization was performed dividing to 4 times because the collection of samples of this comparatively rare disease was necessary for a few years. Aliquots of $1 \mu \mathrm{g}$ of DNA were diluted to a concentration of $1 \times 2^{-11} \mu \mathrm{g}$ by the 2-fold dilution method. The DNAs were blotted using Minifold II Slot-Blotter (Schleicher \& Schuell GmbH, Dassel, Germany) onto nitrocellulose filters after alkaline denaturation followed by neutralization. DNAs were fixed by UV cross linking. Then the filter was incubated in a solution of $50 \%$ deionized formamide, 5X SSC, 5X Denhart's solution, $0.1 \%$ SDS and $100 \mu \mathrm{g} / \mathrm{ml}$ of salmon sperm DNA at $42^{\circ} \mathrm{C}$ for $18 \mathrm{hr}$.

Probe was ${ }^{32} \mathrm{P}$-labeled by random priming to obtain a specific activity of $1-2 \times 10^{9} \mathrm{cpm} / \mu \mathrm{g}$ of DNA. After hybridization, the filter was washed twice with a solution of $2 \mathrm{X} \mathrm{SSC}$ and $0.1 \% \mathrm{SDS}$ at room

TABLE 1. Patients with parathyroid tumor

\begin{tabular}{|c|c|c|c|c|c|c|}
\hline \multicolumn{2}{|c|}{ Cases } & \multicolumn{3}{|c|}{$\begin{array}{c}\text { Tumor } \\
\text { Age Sex Weight (gm.) }\end{array}$} & \multirow{2}{*}{$\begin{array}{c}\begin{array}{c}\text { Histological } \\
\text { Diagnosis }\end{array} \\
\text { Hyperplasia (Chief) }\end{array}$} & \multirow{2}{*}{$\begin{array}{c}\begin{array}{c}\text { Follow-up } \\
\text { Period }\end{array} \\
13 \mathrm{M}\end{array}$} \\
\hline 1) & Y. I. & 45 & $\mathrm{~F}$ & 0.6 & & \\
\hline 2) & M. H. & 52 & $\mathrm{~F}$ & 9.4 & Adenoma (Chief) & $15 \mathrm{M}^{1}$ \\
\hline 3) & M. Y. & 59 & $\mathbf{M}$ & 0.8 & Adenoma (Mixed ${ }^{2}$ ) & $26 \mathrm{M}$ \\
\hline 4) & S. Y. & 43 & $\mathbf{F}$ & 2.0 & Adenoma (Chief) & $24 \mathrm{M}$ \\
\hline 5) & M. T. & 38 & $\mathbf{M}$ & 4.5 & Adenoma (Chief) & $28 \mathrm{M}$ \\
\hline 6$)$ & S. S. & 44 & $\mathbf{M}$ & 1.1 & Adenoma (Chief) & $27 \mathrm{M}$ \\
\hline 7) & K. S. & 60 & $\mathbf{F}$ & 1.4 & Adenoma (Chief) & $23 \mathrm{M}^{3}$ \\
\hline 8) & Y. S. & 52 & $\mathbf{M}$ & 2.0 & Adenoma (Mixed) & $23 \mathrm{M}$ \\
\hline 9) & T. Y. & 48 & $\mathbf{F}$ & 0.6 & Adenoma (Chief) & $40 \mathrm{M}$ \\
\hline 10) & K. A. & 70 & $\mathbf{F}$ & 4.7 & Adenoma (Chief) & $15 \mathrm{M}$ \\
\hline 11) & K. O. & 77 & $\mathbf{F}$ & 3.1 & Adenoma (Mixed) & $12 \mathrm{M}$ \\
\hline 12) & M. I. & 59 & $\mathbf{F}$ & 1.1 & Adenoma (Chief) & $21 \mathrm{M}$ \\
\hline 13) & H. H. & 63 & $\mathbf{F}$ & 0.2 & Adenoma (Chief) & $12 \mathrm{M}$ \\
\hline 14) & M. S. & 38 & $\mathbf{F}$ & 0.6 & Adenoma (Chief) & $15 \mathrm{M}$ \\
\hline 15) & K. K. & 38 & $\mathbf{M}$ & 30.0 & Adenocarci. (Chief) & $29 \mathrm{M}$ \\
\hline
\end{tabular}

1 Radical hysterectomy and lymphadenectomy for the carcinoma of the uterine cervix.

2 Mixed tumor with chief cells and oxyphilic cells.

3 Concomitant papillary thyroid carcinoma. 
TABLE 2: Amplification of c-erbB2 proto-oncogene and immunohistochemical expression of $c$-erbB2 gene product in parathyroid tumors

\begin{tabular}{rrcc}
\hline \multicolumn{2}{c}{ Cases } & $\begin{array}{c}\text { Amplification of } \\
\text { c-erbB2 proto-oncogene }\end{array}$ & $\begin{array}{c}\text { Expression of } \\
\text { c-erbB2 gene product }\end{array}$ \\
\hline 1) & Y. I. & $(-)$ & $(\mathrm{NE})$ \\
\hline 2) & M. H. & X4 & $(-)$ \\
3) & M. Y. & $(-)$ & $(+)$ \\
4) & S. Y. & $(-)$ & $(-)$ \\
5) & M. T. & $(-)$ & $(-)$ \\
6) & S. S. & $(-)$ & $(+)$ \\
7) & K. S. & $(-)$ & $(+)$ \\
8) & Y. S. & $(-)$ & $(-)$ \\
9) & T. Y. & X2 & $(+)$ \\
10) & K. A. & $(-)$ & $(-)$ \\
11) & K. O. & $(-)$ & $(+)$ \\
12) & M. I. & X4 & $($ H) \\
13) & H. H. & $(-)$ & (ND) \\
14) & M. S. & $(-)$ & (ND) \\
\hdashline 15) & K. K. & X8 & (ND) \\
\hline
\end{tabular}

+ : weakly positive. $H$ : strongly positive. ND: Not done.

temperature and four times with $0.1 \%$ SDS at $50^{\circ} \mathrm{C}$. The presence or absence of c-erbB2 oncogene amplification was evaluated from the density of the autoradiograms using the densitometer (model 300A, Molecular Dynamics, Sunnyvale, CA, USA). Samples were considered amplified if the density of the transcripts in a sample was 4-fold or more greater than in the normal control.

\section{Expression of c-erbB2 gene product}

Frozen blocks from 11 parathyroid adenomas were available for the immunohistochemical expression of the c-erbB2 gene products (Tables 1, 2). The primary antibody used for the present experiment was commercially available, anti-erbB2 monoclonal antibody (Nichirei Co., Tokyo, Japan). The dilution of the antibody used was 100 -fold. The avidin-biotin complex method was used for the staining procedure. Five $\mu \mathrm{m}$ sections cut from OCT compound block were fixed with buffered formalin (10 min). After exposure to a mixture of hydrogen peroxide and methanol for inhibition of endogenous peroxidase activity, the sections were treated with inert proteins to block nonspecific protein binding sites. The specimens were incubated overnight at $4^{\circ} \mathrm{C}$ with the primary antibody of dilution above mentioned. Then, the biotinylated bridge serum was applied to the sections to incubate for $30 \mathrm{~min}$ at room temperature. Sections were incubated for $30 \mathrm{~min}$ with the avidin-biotin com- plex. The final complex formed was visualized by exposing the sections to diaminobenzidine. After being counter-stained with $1 \%$ of methyl green, the sections were dehydrated and mounted.

\section{RESULTS}

The microscopic appearances of all tumors were essentially similar. Polygonal cells with dark cytoplasm formed nests arranged in a sheetlike and/or alveolar pattern. Nuclei were slightly hyperchromatic and pleomorphic in some adenomas and adenocarcinoma (Figs. 1, 2). Mitotic figures were not observed in any of the tumors. Cystic degeneration was occasionally seen in some cases. The adenocarcinoma showed the capsular invasion by tumor cells.

The findings of the amplification of the c-erbB2 proto-oncogene and the expression of the c-erbB2 gene product are summarized in Table 2. The c-erbB2 proto-oncogene was amplified (over 4-fold) in an adenocarcinoma, and 2 adenomas (15.4\% of all adenomas), and slightly (2-fold) amplified in one case of the other adenoma (7.7\% of all adenomas) in comparison to the control (Fig. 3).

The immunohistochemical expression of the cerbB2 gene product was recognized in 6 cases of 11 adenomas $(54.5 \%)$. In three cases, staining of adenoma cells was stronger ( $H$ positive) than in the other cases ( + positive) (Table 2 ). The positive stain- 


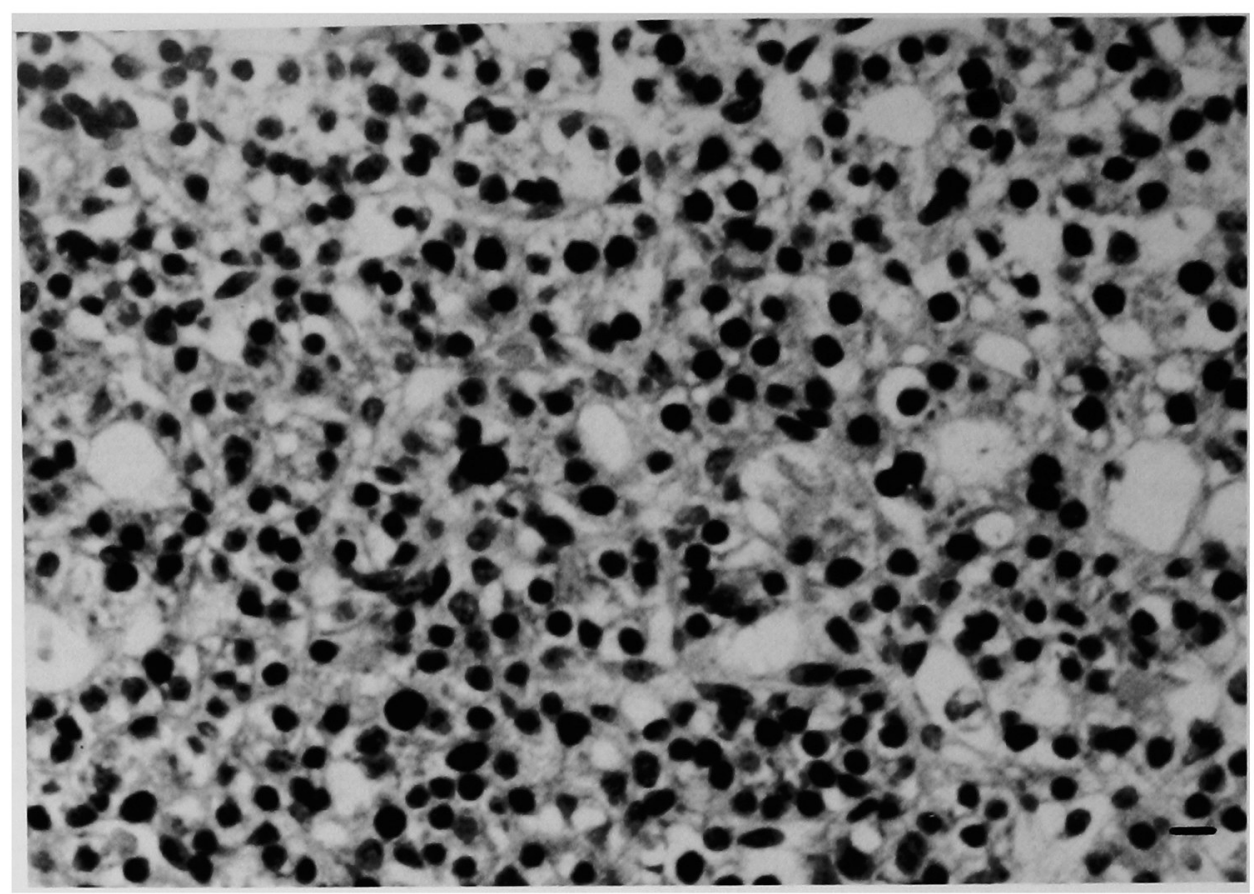

Fig. 1. A parathyroid adenoma which showed the amplification of the c-erbB2 proto-oncogene (Case T. Y.; H.E. stain). The adenoma cells are arranged in an acinar pattern. The nuclei are slightly hyperchromatic and pleomorphic. Bar $=10 \mu \mathrm{m}$.

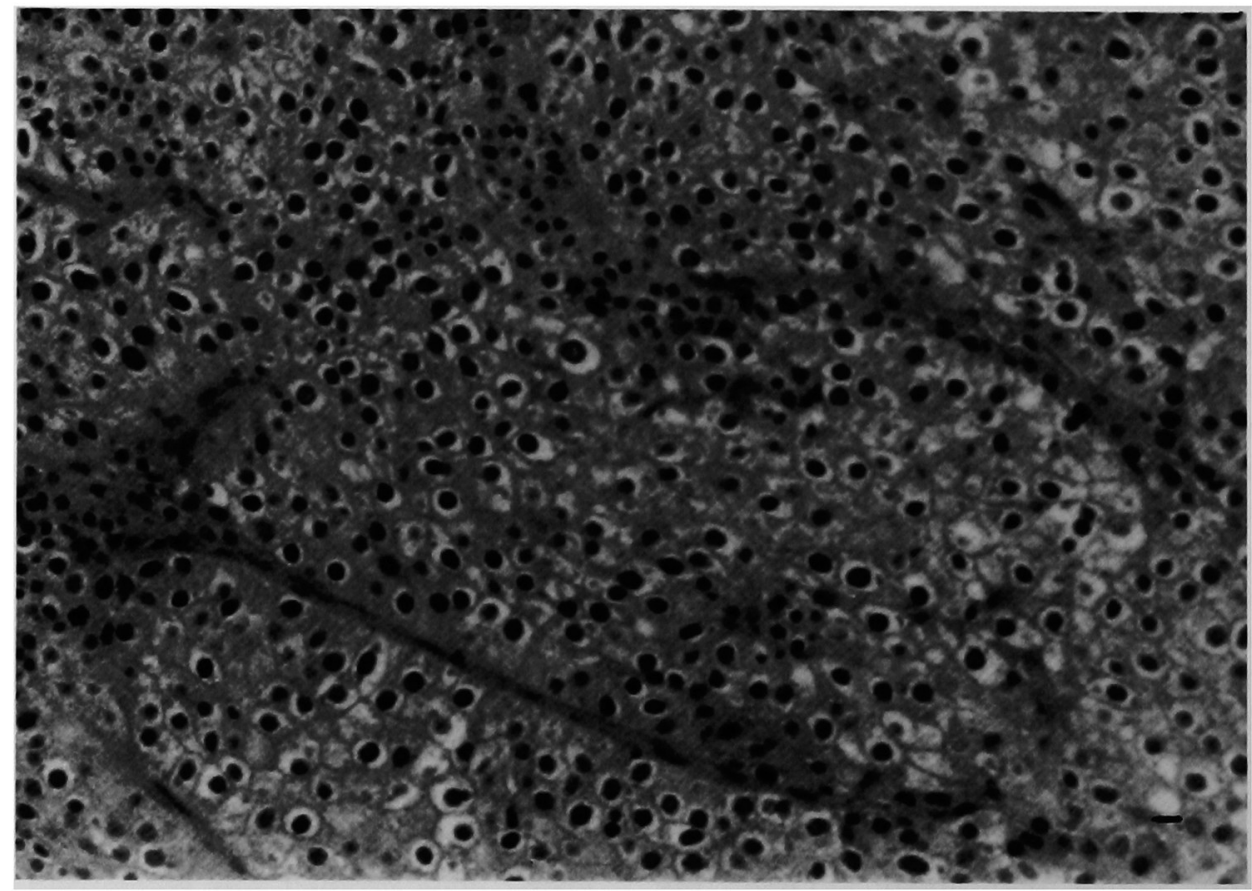

Fig. 2. The parathyroid adenocarcinoma which showed the significant amplification of the c-erbB2 proto-oncogene (Case K. K.; H.E. stain). The tumor cells are arranged in a trabecular pattern. Nuclei are almost the same as in case T. Y. Bar $=10 \mu \mathrm{m}$. 


\section{Amplification of c-erb B2}
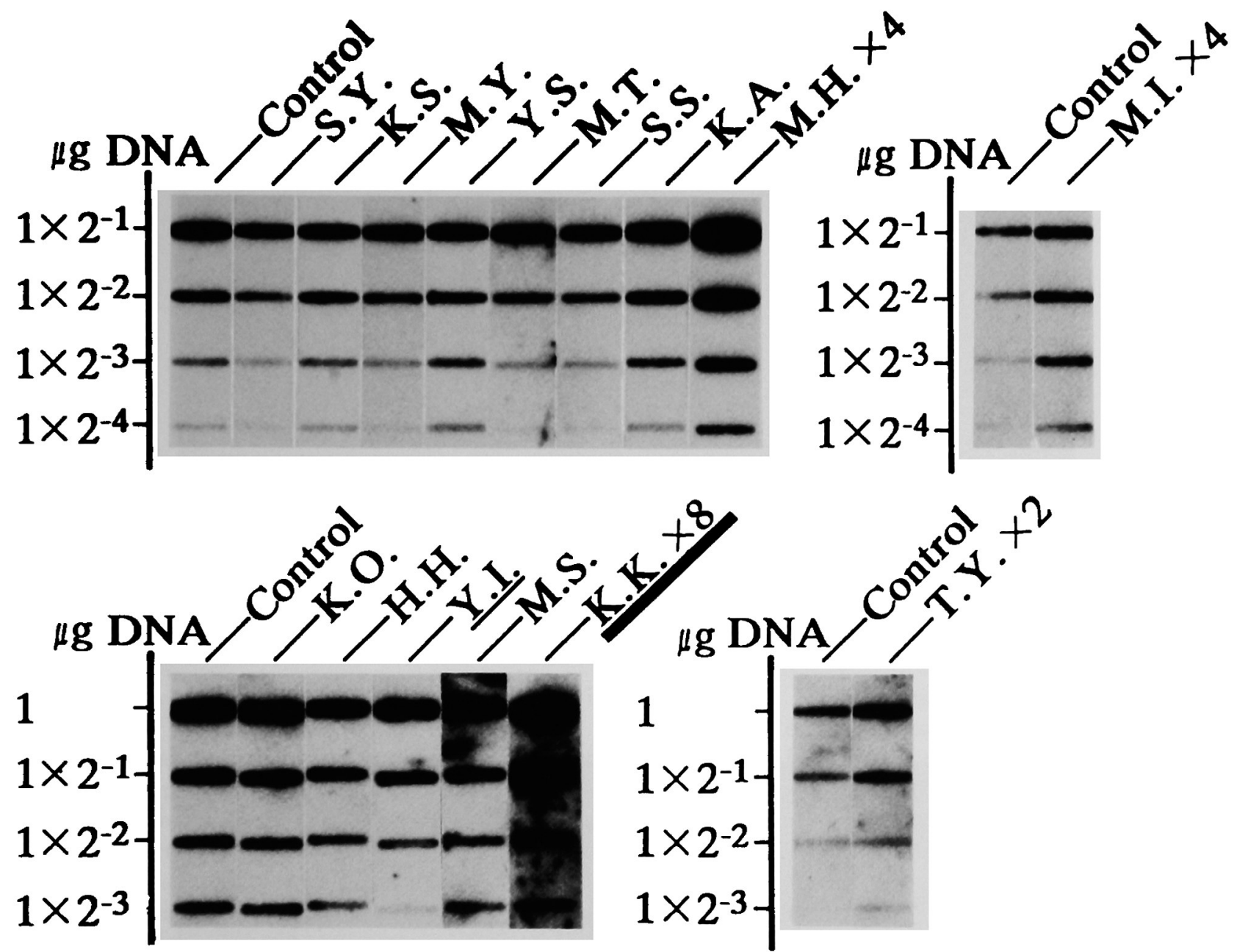

Fic. 3. The amplification of c-erbB2 proto-oncogene. The case with a thick under-line on the figure is the parathyroid adenocarcinoma, and that with a thin under-line is the parathyroid hyperplasia. The multiplied numbers indicated the amplification rates. The slot blot hybridization was performed dividing to four times.

ing was recognized on the cell membrane of the proliferating adenoma cells, and some areas of the cytoplasm of adenoma cells (Figs. 4, 5). The luminal surface of some tubular areas of the adenoma showed weakly positive staining. Stroma was not stained (Fig. 6).

Two adenomas having the amplification of the cerbB2 proto-oncogene were strong $(H)$ positive for the immunohistochemical staining of the c-erbB2 gene product. The other 4 adenomas with positive immunohistochemical staining demonstrated no amplification of the c-erbB2 proto-oncogene. One adenoma demonstrating the 4-fold amplification of the
c-erbB2 proto-oncogene was negative for the staining (Table 2).

\section{DISCUSSION}

The parathyroid adenoma is the most frequent $(81 \%)$ in primary hyperparathyroidism (4). In the pathological criteria for distinguishing parathyroid carcinomas from adenomas, mitoses and nuclear sizes within parenchymal cells are the most valuable criteria. However, about $10 \%$ of adenomas have nuclei which are very large and hyperchromatic (4). Therefore, the different diagnosis between adenocar- 


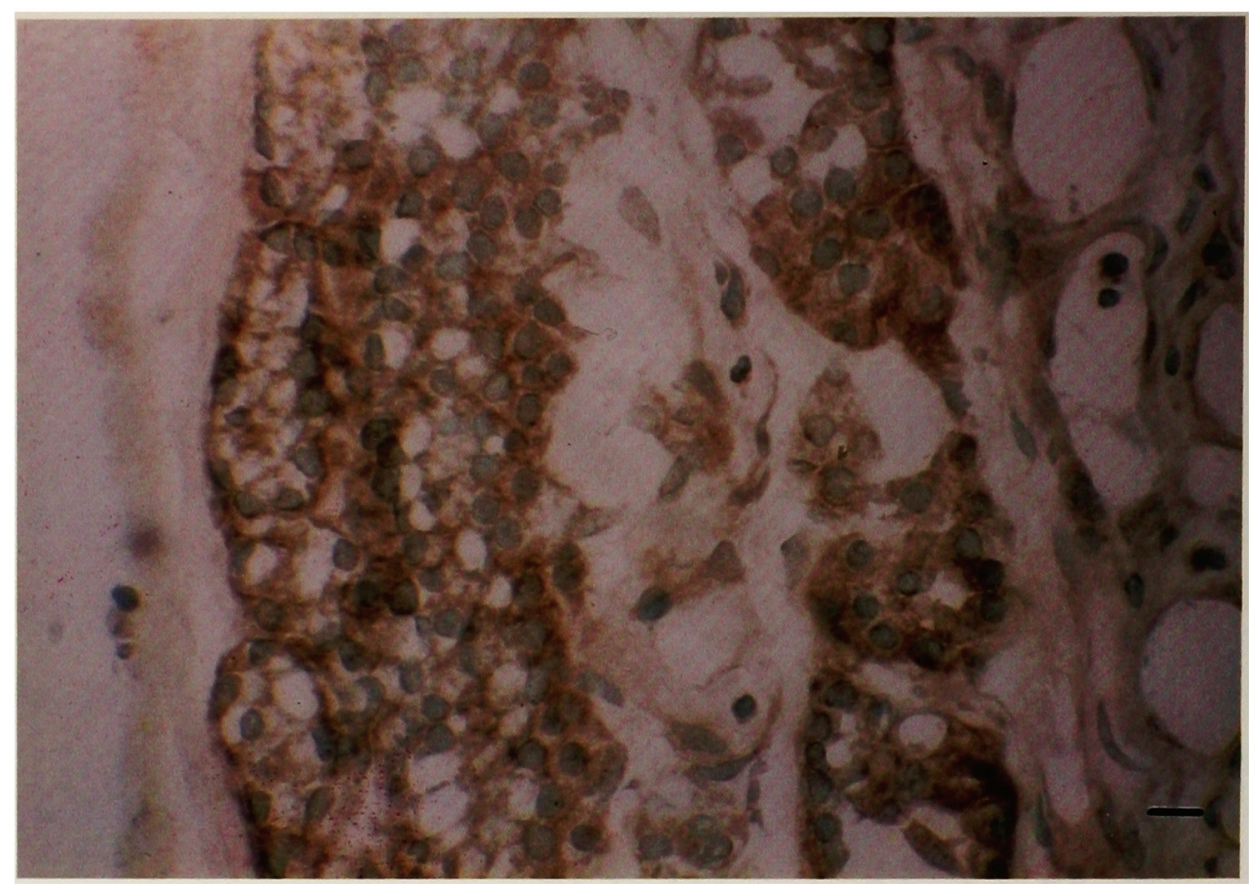

Figs. 4-6. Immunohistochemical expression of c-erbB2 gene product.

Fig. 4. The strong positive staining was recognized on the cell membrane and in the cytoplasm. The case did not reveal any amplification of the c-erbB2 proto-oncogene (Case S. S.). Bar $=10 \mu \mathrm{m}$.

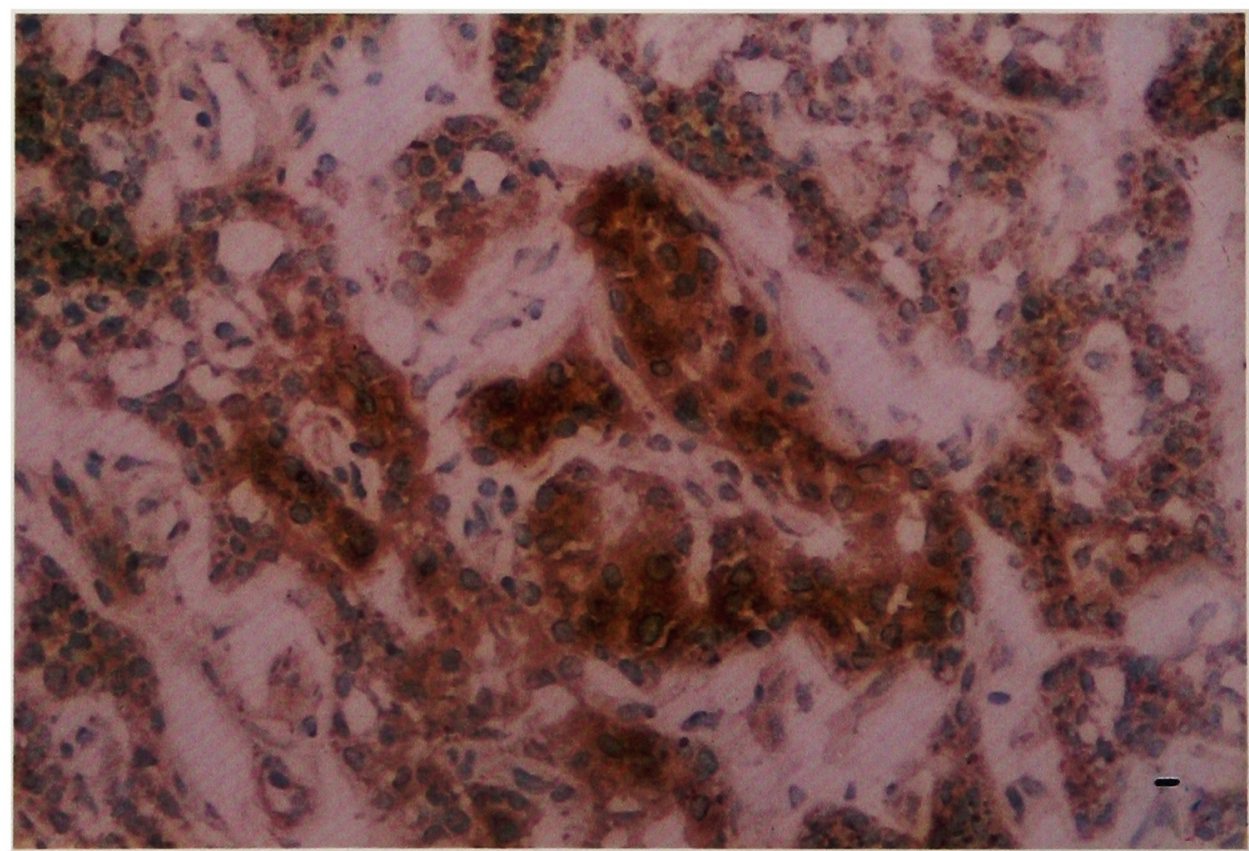

FIG. 5. The strong positive staining was demonstrated in the cytoplasm of the adenoma cells. The cytoplasm of the other areas of the adenoma cells also revealed weak staining. This case demonstrated the 4-fold proto-oncogene amplification (Case T. Y.). Bar $=10 \mu \mathrm{m}$. 


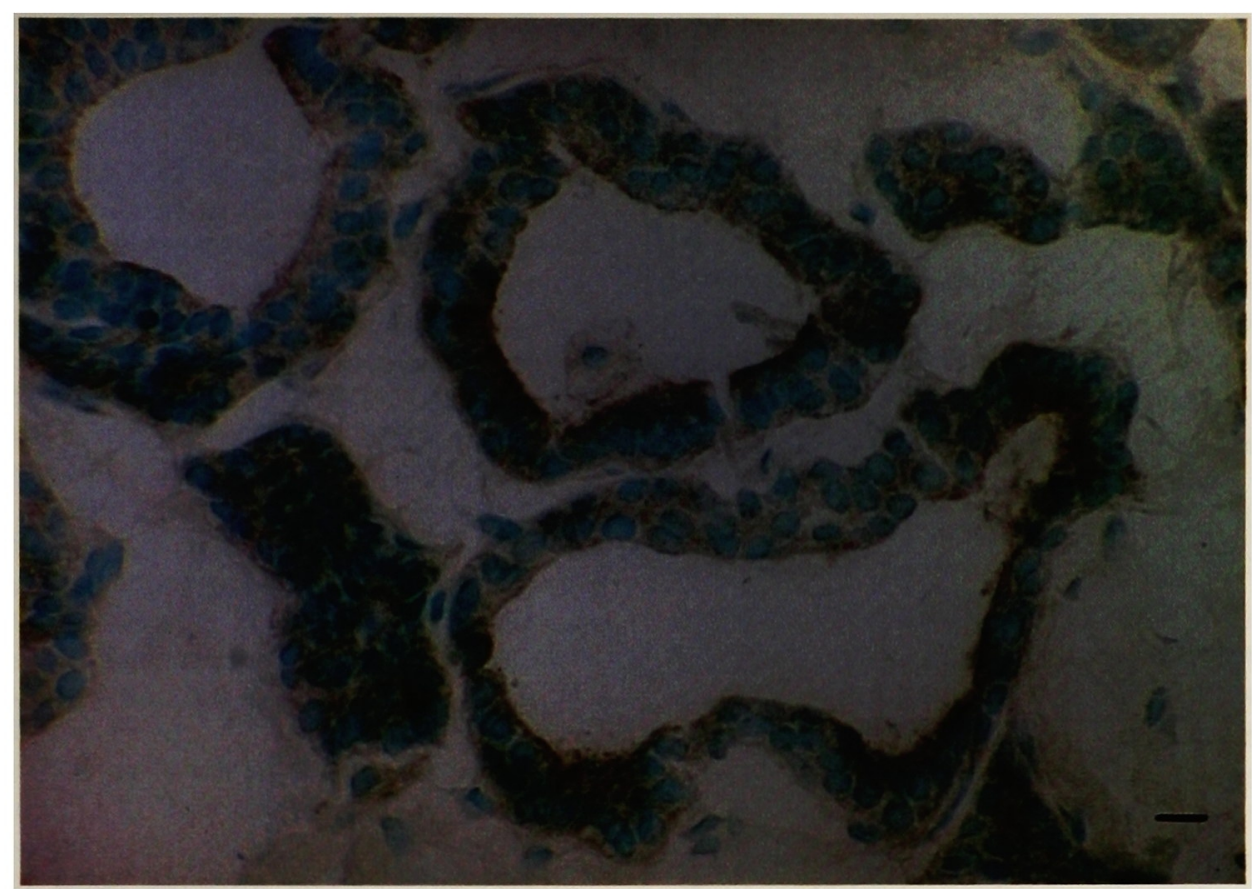

Fig. 6. The luminal surface of the tubular area of the parathyroid adenoma showed weak positive staining. This case also revealed no proto-oncogene amplification (Case K. S.). $\mathrm{Bar}=10 \mu \mathrm{m}$.

cinomas and adenomas of parathyroid glands is difficult.

Oncogenes can contribute to neoplastic transformation when point mutation (23), DNA rearrangement (7), or oncogene amplification (3) alters the oncogene product itself or affects its pattern of expression. In this study, the c-erbB2 gene was examined for parathyroid tumors, because this gene was reported to be amplified or expressed in human adenocarcinomas including breast, stomach and pancreas etc. $(2,10,13,16,18,22,27)$. The significance of amplification of this oncogene was controversial. There are 2 different reports that c-erbB2 gene correlates with metastasis and patient survival in breast cancer $(20,24)$ or not $(6,27)$.

For the criterion of the amplification, Seeger $e t$ al. (19) and Yao et al. (25) considered as significant if the density of the transcript in a tumor sample was 3-fold greater than that of normal. We conveniently adopted 2-fold for the criterion of the amplification according to the paper of Venter et al. (24). Two-fold amplification might be considered a slight amplification or border line. We compared the amplification of the c-erbB2 proto-oncogene in parathyroid tumors and control (pooled human normal placenta), and demonstrated the amplification of the c-erbB2 protooncogene in 3 adenomas and 1 adenocarcinoma
(Table 2). The present result for parathyroid adenoma or adenocarcinoma appears to be reasonable, because the c-erbB2 oncogene (also called neu and HER2) is considered to encode a cell-surface tyrosine kinase structurally related to the receptors of epidermal growth factor (EGF) (26) and of glandular epithelium (13).

For the immunohistochemical study of c-erbB2 gene product, the positive rates were different in various literature and ranged from $17-83 \%(10,16$, $17,24)$. Our study showed $54.5 \%$ of positive staining (including 3 cases of weak staining). The localization was reported mainly on the cytoplasmic membrane $(16,17)$, but the cytoplasmic staining was reported especially with the polyclonal antibody $(10,24)$. Present cases also revealed the focal cytoplasmic staining. The reason for this was obscure. Formalin-fixed paraffin-embedded specimens were reported to also be useful for the immunohistochemical study of the cerbB2 gene product $(10,24)$. We used the frozen sections, because the clear staining of cell membrane had been available. Further trials with paraffin section are being performed.

On breast cancer, Venter et al. (24) reported the good correlation between the expression of c-erbB2 oncoprotein (gene product) and the amplification of cerbB2 gene. Two gene amplified cases showed good 
correlation to immunohistochemical staining, but another case with amplified c-erbB2 gene demonstrated no positive staining. For this case, recent carcinoma of the uterine cervix (one year ago) may get involved with the gene amplification. The 4 cases which showed positive staining of c-erbB2 gene products, demonstrated no gene amplification. The interpretation of this discrepancy was arguable. The meaning of the weak staining was also difficult to interpret. The immunohistochemical staining of c-erbB2 gene product might become a landmark of gene amplification for c-erbB2 proto-oncogene.

There have been no previous reports of the analysis of c-erb B2 gene in parathyroid tumors. For other oncogene, Friedman et al. (9) detected no point mutation of $\mathrm{H}$-ras, $\mathrm{K}$-ras and $\mathrm{N}$-ras in any sporadic parathyroid adenoma. This study has provided the information on the oncogene amplification in the human parathyroid adenoma and adenocarcinoma. There might be some arguments for the control of the Southern blotting. Furthermore, the possibility that the amplification of genes was an acquired abnormality, has not been elucidated, because the normal parathyroid and other tissues of the patients were not analyzed. It was of interest that some adenomas as well as the adenocarcinoma showed the amplification of the c-erbB2 proto-oncogene. Our study has to be extended to resolve the mechanism of the gene activation and to aid in the differential diagnosis of the parathyroid adenoma and adenocarcinoma.

\section{ACKNOWLEDGEMENT}

We wish to thank Mitsubishi Yuka, Biochemical Laboratory, Co. for the technical help with this study. This study was supported in part by a Grantin-Aid from the Ministry of Education, Science and Culture, JAPAN (02670700).

\section{REFERENCES}

1. Arnold, A., Staunton, C. E., Kim, H. G., Gaz, R. D. and Kronenberg, H. M.: Monoclonality and abnormal parathyroid hormone genes in parathyroid adenomas. New Engl. J. Med. 318; 658-662, 1988.

2. Borg, A., Baldetorp, B., Ferno, M., Killander, D., Olsson, H. and Sigurdsson, H.: ERBB2 amplification in breast cancer with a high rate of proliferation. Oncogene 6 ; 137-143, 1991.

3. Brodeur, G. M., Seeger, R. C., Schwab, M. Varmus, H. E. and Bishop, J.M.: Amplification of N-myc in untreated human neuroblastomas correlates with advanced disease stage. Science 224; 1121-1124, 1984.
4. Castleman, B. and Roth, S.I.: Tumors of the parathyroid glands. Fascicle 14, Atlas of Tumor Pathology. Washington: Armed Forces Institute of Pathology, 1978.

5. Christmas, T. J., Chapple, C. R., Noble, J. G., Milroy, E. J.G. and Cowie, A. G. A.: Hyperparathyroidism after neck irradiation. Br. J. Surg. 75; 873-874, 1988.

6. Cline, M. J., Battifora, H. and Yokota, J.: Proto-oncogene abnormalities in human breast cancer: Correlations with anatomic features and clinical course of disease. J. Clin. Oncol. 5; 999-1006, 1987.

7. Croce, C. M. and Nowell, P. C.: Molecular basis of human B-cell neoplasia. Blood 65; 1-7, 1985.

8. Friedman, E., Sakaguchi, K., Bale, A. E., Falchetti, A., Streeten, E., Zimering, M. B., Weinstein, L. S., McBride, W. O., Nakamura, Y., Brandi, M-L., Norton, J. A., Aurbach, G. D., Spiegek, A. M. and Marx, S. J.: Clonality of parathyroid tumors in familial multiple endocrine neoplasia type 1 . New Engl. J. Med. 321; 213218, 1989.

9. Friedman, E., Bale, A. E., Marx, S. J., Norton, J. A., Arnold, A., Tu, T., Aurbach G. D. and Spiegel, A. M.: Genetic abnormalities in sporadic parathyroid adenomas. J. Clin. Endocrinol. Metab. 71; 293-297, 1990.

10. Hall, P. A., Hughes, C. M., Staddon, S. I., Richman, P. I., Gullick W. J. and Lemoine, N. R.: The c-erbB-2 proto-oncogene in human pancreatic cancer. J. Pathol. $161 ; 195-200,1990$.

11. Katz, A. and Braunstein, G. D.: Clinical, biochemical, and pathologic features of radiation-associated hyperparathyroidism. Arch. Intern. Med. 143; 79-82, 1983.

12. Kremer, R., Bolivar, I., Goltzman, D. and Hendy, G. N.: Influence of calcium and 1,25-dihydroxycholecalciferol on proliferation and proto-oncogene expression in primary cultures of bovine parathyroid cells. Endocrinology 125; 935-941, 1989.

13. Masuda, H., Battifora, H., Yokota, J., Meltzer, S. and Cline, M. J.: Specificity of proto-oncogene amplification in human malignant disease. Mol. Biol. Med. 4; 213-21, 1987.

14. Maniatis, T., Fritsch, E. F. and Sambrook, J.: Molecular Cloning. A Laboratory Manual. Cold Spring Harbor, N.Y. Cold Spring Harbor Laboratory, 1982.

15. Meyers, D. A., Beaty, T. H., Maestri, N. E., Kittur, S. D., Antonarakis, E. S. and Kazazian, H. H., Jr.: Multipoint mapping studies of six loci on chromosome 11. Hum. Hered. 37; 94-101, 1987.

16. Mori, S., Akiyama, T., Morishita, Y., Shimizu, S., Sakai, K., Sudoh, K., Toyoshima, K. and Yamamoto, T.: Light and electron microscopical demonstration of cerb B-2 gene product-like immunoreactivity in human malignant tumor. Virchows Arch. B 54; 8-15, 1987.

17. Moriyama, M., Akiyama, T., Yamamoto, T., Kawamoto, T., Kato, T., Sato, K., Watanuki, T., Hikage, T., Kastuta, N. and Mori, S.: Expression of CERBB-2 gene product in urinary bladder cancer. $J$. Urol. 145;423-427, 1991.

18. Riviere, A., Becker, J. and Loning, T.: Comparative in- 
vestigation of c-erbB2/neu expression in head and neck tumors and mammary cancer. Cancer 67; 2142-2149, 1991.

19. Seeger, R. C., Brodeur, G. M., Sather, H., Dalton, A., Siegel, S. E., Wong, K. Y. and Hammond, D.: Association of multiple copies of the $\mathrm{N}$-myc oncogene with rapid progression of neuroblastomas. N. Engl. J. Med. 313; 1111-1116, 1985.

20. Slamon, D. J., Godolphin, W., Jones, L. A., Holt, J. A., Wong, S. G., Keith, D. E., Levin, W. J., Stuart, S. G., Udove, J., Ullrich, A. and Press, M. F.: Studies of the HER-2/neu proto-oncogene in human breast and ovarian cancer. Science 244; 707-712, 1989.

21. Thakker, R. V., Bouloux, P., Wooding, C., Chotai, K., Broad, P. M., Spurr, N. K., Besser, G. M. and O'Riordan, J. L.: Association of parathyroid tumors in multiple endocrine neoplasia type 1 with loss of alleles on chromosome 11. New Engl. J. Med. 321; 218-224, 1989.

22. Tsujino, T., Yoshida, K., Nakayama, H., Ito, H., Shimosato, T. and Tahara, E.: Alterations of oncogenes in metastatic tumours of human gastric carcinomas. Br.
J. Cancer 62; 226-230, 1990.

23. Weinberg, R.A.: Ras oncogenes and the molecular mechanisms of carcinogenesis. Blood 64; 1143-1145, 1984.

24. Venter, D. J., Tuzi, N. L., Kumar, S. and Gullick, W.J.: Over-expression of the c-erbB-2 oncoprotein in human breast carcinomas: immunohistological assessment correlates with gene amplification. Lancet 11; 6972, 1987.

25. Yao, M., Shuin, T., Misaki, H. and Kubota, Y.: Enhanced expression of c-myc and epidermal growth factor receptor genes in primary human renal cancer. Cancer Res. 48; 6753-6757, 1988.

26. Yarden, Y. and Peles, E.: Biochemical analysis of the ligand for the neu oncogenic receptor. Biochemistry 30; 3543-3550, 1991.

27. Zhou, D., Battifora, H., Yokota, J., Yamamoto, T. and Cline, M. J.: Association of multiple copies of the cerbB-2 oncogene with spread of breast cancer. Cancer Res. 47; 6123-6125, 1987. 